\title{
Ūkių ekonominị gyvybingumą lemiančių veiksnių vertinimas Lietuvos ūkininkų ùkių pavyzdžiu
}

Jūratė Savickienè,

\section{Astrida Slavickienè}

Aleksandro Stulginskio universitetas, Universiteto g. 10,

LT-53361 Akademija, Kauno r.

El.paštas: jurate.savickiene@asu.lt; astrida.slavickiene@asu.lt
Moksliniuose tyrimuose mažai dėmesio skiriama ūkių ekonominiam gyvybingumui vertinti, tinkamai parinkti ir taikyti vertinimo modelius. Todèl mokslinè problema - įvertinti veiksnių ịtaką ūkių ekonominiam gyvybingumui ir identifikuoti svarbiausius ekonomini gyvybingumą apibūdinančius rodiklius, išlieka aktuali ir yra nagrinejjama šiame tyrime. Mokslininkų tyrimų rezultatai parodè, kad ūkio ekonominio gyvybingumo apibrěžimas yra sudètingas kintamasis, kurio koncepcija dar nèra išbaigta ir kuriam visapusišką paaiškinimą nẻra taip lengva surasti. Todèl būtina suformuluoti ūkio ekonominio gyvybingumo apibrèžimą, bent lokalaus tyrimo tikslams, siekiant apibrěžti ūkio ekonominio gyvybingumo vertinimo rodiklius, nes iškyla palyginimo bei teisingo duomenų interpretavimo problema. Straipsnyje susisteminti ūkių ekonominị gyvybingumą lemiantys veiksniai ir nustatyti finansiniai rodikliai, vertinantys Lietuvos ūkininkų ūkius, laikytini esmingiausiais ūkio ekonominio gyvybingumo vertinimo požiūriu. Nustatyti ūkių ekonominio gyvybingumo rodikliai, greičiausiai atskleidžiantys ūkio veiklos trikdžius. Tačiau išlieka problema, kuriuos finansinius rodiklius taikyti, kurie rodikliai yra svarbesni. Tyrimui atlikti buvo parinkti mokslinèje literatūroje dažniausiai naudojami finansiniai rodikliai ūkių ekonominiam gyvybingumui vertinti ir nustatyta, kad pasirinkti rodikliai yra tinkami ir svarbūs.

Raktažodžiai: ekonominis gyvybingumas, ekonominio gyvybingumo vertinimas, finansiniai veiksniai, finansiniai rodikliai, ūkininko ūkis, analizè

\section{IVADAS}

Didejant maisto sektoriaus svarbai pasaulyje, vystantis subalansuotos plètros idejjai, ūkių ekonominis gyvybingumo vertinimas tampa vis aktualesne ir labiau diskutuotina tema. Pasaulyje bei Lietuvoje žemès ūkio verslas, tuo pačiu ir ūkių ekonominis gyvybingumas, palaikomas įvairiomis priemonemis: parama, lengvatinių paskolų teikimu bei mokesčių politikos priemonèmis. Taigi ūkių ekonomini gyvybingumą veikia daugelis i̇vairių veiksnių, kurių įtaka atskirų valstybių ūkių ekonominiam gyvybingumui skiriasi dèl šalies vykdomos paramos bei mokesčių politikos, taikomos ùkių skatinimo sistemos ir kt. Vykdant žemès ūkio ateities bendrosios žemès ùkio politikos reformą, vienas iš Europos Sąjun- gos prioritetinių tikslų moksliniuose tyrimuose 2014-2020 m. yra gyvybinga maisto produktu gamyba, kuri turi didinti žemès ūkio sektoriaus gyvybingumą, skatindama ūkių tvarumą, pažangą ir integracinị augimą kaimo vietovèse.

Aktkūrus šalies Nepriklausomybę, dideli pertvarkymai vyko žemès ūkio sektoriuje. Kūrèsi ūkininkų ūkiai, žemès ūkio bendrovès. Vienas svarbiausių uždavinių buvo skatinti ūkių ekonomini gyvybingumą. Tam reikejo najų mokslinių tyrimų. Mokslininkai (Adelaja, Sullivan, 1998; Argiles, 2001 ir kt.; Singh, Bhillar, Joshi, 2001; Popelier, 2005) iki šiol neturi vieningos nuomonès, kokie veiksniai sąlygoja ūkių gyvybingumą. Dažniausiai mokslininkai (Scott, 2001; Adelaja, 2005; Scott, 2005 ir kt.) siekia ịvertinti ūkių ekonomini gyvybingumą, pasitelkdami santyki- 
nius finansinius rodiklius ir statistinius metodus. Atlikta nemažai tyrimų siekiant įvertinti mažų ūkių pajamų ir jų šaltinių priežastis (Whitaker, 2009 ir kt.). H. C. J. Vrolijk, C. J. Bont, P. W. Blokland et al. (2010) tyrè galimą poveikị ūkių ekonominiam gyvybingumui, sumažinus žemès ūkio išmokas. E. Scotti, H. Bergmann, R. Henke et al. (2011) vertino tiesioginès paramos poveikị ūkių pajamoms ir ūkio ekonominiam gyvybingumui. D. Conner, K. Colasanti, R. Brent et al. (2009) tyrè veiksnius, kurie prisideda prie žemès ūkio sektoriaus ekonominio gyvybingumo didinimo, tačiau nevertino jų poveikio ūkių ekonominio gyvybingumo kitimui. Pastebima, kad moksliniuose tyrimuose mažai dèmesio skiriama vertinant ūkių ekonominị gyvybingumą, tinkamai parenkant ir taikant vertinimo modelius, analizuojant veiksnių ịtaką atskirose šalyse. Lietuvoje gyvybingumo sąvoka suprantama labai siaurai ir moksliniu požiūriu nekorektiškai, gyvybingumas ir ji lemiantys veiksniai Lietuvos ūkiuose netirti. Todèl keliama moksliné problema - ivvertinti veiksnių ittaką ūkių ekonominiam gyvybingumui ir identifikuoti svarbiausius ekonomini gyvybingumą apibūdinančius rodiklius, išlieka aktuali ir yra nagrinejjama šiame tyrime. Problema aktuali tiek teoriniu, tiek ir praktiniu požiūriu. Tyrimo naujumas grindžiamas parenkant ekonomini gyvybingumą lemiančius svarbiausius veiksnius, lyginant mokslininkų siūlomus veiksnius ir empirinių tyrimų gautus rezultatus.

Tyrimo objektas - ūkio ekonominị gyvybingumą lemiantys veiksniai ir jų rodikliai.

Tyrimo tikslas - išanalizavus ūkių ekonominị gyvybingumą lemiančius veiksnius ir ji apibūdinančius rodiklius, identifikuoti svarbiausius ekonominị gyvybingumą lemiančius veiksnius.

Darbo tikslui pasiekti keliami uždaviniai:

- pateikti ūkių ekonominio gyvybingumo apibrèžtị tyrimų kontekste;

- apibendrinti mokslininkų tiriamus ūkių ekonominio gyvybingumo veiksnius ir rodiklius;

- nustatyti taikomų finansinių rodiklių patikimumą ekonominiam gyvybingumui vertinti Lietuvos ūkininkų ūkių pavyzdžiu;

- naudojant porinès ir dalinès koreliacinès analizès metodus nustatyti ūkių ekonominio gyvybingumo veiksnius ir parinkti reikšmingiausius.

\section{METODAI IR SĄLYGOS}

Ekonominio gyvybingumo samprata suformuluota remiantis mokslinès literatūros analizès, apibendrinimo bei palyginimo metodais. Ūkių ekonomini gyvybingumą lemiantys veiksniai atrinkti naudojant sisteminę ir lyginamąją mokslinès literatūros analizę bei sintezę, siejant veiksnius su ūkio ekonominio gyvybingumo vertinimo rodikliais, tyrimo kontekste. Ūkių ekonomini gyvybingumą lemiantys veiksniai atrinkti ìvertinus porinès ir dalinès koreliacijos koeficientų ryšio stiprumą ir reikšmingumą. Remiantis užsienio mokslininkų empiriniais moksliniais tyrimais bei loginès analizès ir sintezès būdu nustatyta, kad svarbesni yra finansiniai rodikliai. Šiam teiginiui ịrodyti atliktas Lietuvos respondentinių ūkių empirinis tyrimas, statistinès informacijos sisteminimo bei grupavimo metodais ịvertintas šių ūkių gyvybingumas ir jo pokyčiai. Naudojant koreliacinès analizès metodus ir grafinio vaizdavimo būdus atliktas analizuojamų rodiklių finansinio patikimumo tyrimas. Apibendrinimo metodu suformuluotos išvados. Tyrimui naudoti Ūkių veiklos (ŪADT) 20032010 m. duomenys.

\section{REZULTATAI IR JŲ APTARIMAS}

\section{Ekonominio gyvybingumo samprata}

Aktyvus noras nustatyti ūkių ekonomini gyvybingumą dar anksčiau nei prieš 40 metų skatino nemažai ekonomikos srities mokslinių tyrimų. Vienas iš pirmųjų pasiūlęs ekonominio gyvybingumo apibrèžtị buvo V. Bull (1976). Jis apibūdino tai kaip valstybès, regiono, miesto, ūkio ar pan. tvaraus augimo ir gerovès matą vienam gyventojui. Tačiau labiau išsamesnius tyrimus atliko E. Tuma ir H. Drabkin (1978), kurie teige, kad ekonominis gyvybingumas yra išmatuojamas augimo ir plètros pajègumu siekiant ekonominių tikslų (Fedorčenko, 2008).

Mokslinejje literatūroje galima aptikti įvairių ūkio ekonominio gyvybingumo sąvokų interpretacijų, tai priklauso nuo tam tikrų vertinimo aspektų ar tikslų. Ekonominis gyvybingumas - dažnai vartojamas terminas. Tačiau ekonominejje terminologijoje jo reikšmė praradusi apibrèžtumą.

Ekonominio gyvybingumo sąvoka galètų būti traktuojama pagal Europos Tarybos reglamenta 
(EB) Nr. 1257/1999 bei Europos Komisijos rekomendacijas dèl valstybės pagalbos žemès ūkio sektoriui (Council Regulation (EC) No. 1257/1999). Tačiau šiuose teisès aktuose nurodoma, kad ekonominis gyvybingumas - tai esamos ūkio būklès ivvertinimas, o tik po to ükio ateities perspektyvos nustatymas, kurio atitikimas tam tikriems kriterijams leidžia pasinaudoti Europos Sąjungos programų parama. Gyvybingumo vertinimo aspektu siekiama nustatyti, ar ūkinio subjekto būklè pagal priimtus kriterijus vertintina teigiamai (Rakštys, Serva, 2005).

Ekonominis gyvybingumas mikroekonominiu lygmeniu suprantamas kaip santykis tarp ūkio realių ar potencialių veiklos išlaidų bei pajamų. Kitaip tariant, jei ūkio veiklos išlaidos viršija pajamas, jis nèra ekonomiškai gyvybingas. Taigi nagrinejjant ekonominị gyvybingumą, būtina detaliai išanalizuoti ūkių pajamas ir išlaidas, jų struktūrą (Gulbinas, Balvačiūtè, 2008).

Užsienio mokslinèje literatūroje ūkių ekonominis gyvybingumas apibūdinamas plačiau, sąvoka apima pelningą ūkio veiklą, ùkio dydį, ūkininko išsilavinimą, sugebejimą išlaikyti šeimą, stabilų ūkio augimą, teigiamą kapitalo grąžą, investicijas i naujas technologijas, inovacijas ir pan. (Adelaja, Sullivan, 1998; Popelier, 2005; Scott, 2005 ir kt. ; Adelaja, Garcia, Gibson et al., 2007; Conner, Colasanti, Brent et al., 2009).

A. Adelaja, K. Sullivan (1998) taip pat pateikè savo ūkio ekonominio gyvybingumo versiją. Anot jų, ekonominis gyvybingumas atspindi ùkio ekonominę ir finansinę būklę, todèl užima itin svarbią vietą, nes ekonominis gyvybingumas lemia ūkio gebejimą optimaliai naudojant turimus išteklius tiekti produkciją ar teikti aukštos kokybès paslaugas. Be to, ekonomiškai gyvybingi ūkiai sugeba gautas lèšas investuoti ị išteklių kokybès gerinimą ir taip didinti tiekiamos produkcijos ar teikiamu paslaugų kokybę. Ūkių ekonominis gyvybingumas yra glaudžiai susijęs su verslo veiklos rezultatais. Jei jie yra prasti, negalima tikètis, kad ūkiai pasižymès dideliu ekonominiu gyvybingumu (Popelier, 2005).

Tyrejai naudoja ir daugiau ūkių ekonominio gyvybingumo apibrèžties variacijų. J. Scott (2005) teigia, kad tai ilgalaikis išlikimas rinkoje siekiant ūkio veiklos tikslų ir vykdant ilgalaikę misiją (Scott, 2005).

Ūkis ekonomiškai gyvybingas, kai dèl kapitalo ir bendrųjų sąnaudų, pardavimų ir produkcijos kainų politikos ūkis tampa pelningu bei atitinka šiuolaikinès ekonomikos sąlygas. Ūkis turi teigiamus pinigu srautus, yra likvidus bei mokus, tenkinantis rinkos reikalavimus ir neturi problemų dèl mokejjimų, t. y. kreditų, palūkanų ir kitų ịsipareigojimų (Fedorčenko, 2008).

Šiek tiek kitoki požiūrị i ūkių ekonominio gyvybingumą pateikia A. Adelaja, K. M. Garcia, A. M. Gibson et al. (2007). Autoriai teigia, kad ūkio ekonominis gyvybingumas priklauso nuo ūkininko išsilavinimo, žinių, kompetencijų, požiūrio, gebejimo prisitaikyti darbo rinkoje, nes labiau išsilavinę uždirba daugiau negu mažiau išsilavinę. Valstybė, skirianti daugiau lèšų švietimui, vystosi greičiau nei skirianti mažiau lèšų. Žmogiškasis ir fizinis kapitalas yra papildantys vienas kitą. Neįmanoma pasirinkti ir investuoti tik $\mathfrak{i}$ žmogų ar $\mathfrak{i}$ brangią ịrangą, būtina investuoti ị abu, nes tik tada tikètinas pelnas (ilguoju laikotarpiu), auga šalies ir ūkio ekonomika.

Ūkio ekonominio gyvybingumo augimą besivystančiuose regionuose ypač akcentuoja neturtingų šalių arba šių šalių ekonomiką nagrinèjantys mokslininkai, kadangi tai viena realiausių galimybių neturtingiems tokių šalių ūkininkams vystyti ekonominę veiklą bei gauti kuo daugiau pajamų, kad būtų galima sumažinti globalaus skurdo lygi (Somba, Kamuanga, Tillens, 2005; Singh, Bhillar, Joshi, 2009).

Europos Komisija (1991a) pateikia platesnę ir konkretesnę ekonominio gyvybingumo prasmę, t. y. pelnas turi sudaryti apie $80 \%$ vidutinio darbo užmokesčio tame regione ir du trečdalius mokamų palūkanų už kapitalą (Argiles, 2001). J. M. Argiles pritaria šiam teiginiui ir priduria, kad ūkininkai lygina visas savo pajamas su darbo užmokesčiu, gautu kitose darbo vietose, o už kapitalą atlygio nesitiki.

Apibendrindamos ịvairias mokslininkų pateiktas ūkio ekonominio gyvybingumo sąvoku interpretacijas, autorès mano, kad tai sudètingas kintamasis ir dèl to kol kas nèra, kaip pripažista ne vienas autorius (Adelaja, Sullivan, 1998; Popelier, 2005; Rakštys, Serva 2005; Adelaja, Garcia, Gibson et al., 2007; Conner, Colasanti, Brent et al., 2009 ir kt.), pakankamai išbaigto apibrèžimo, ivvardijančio visus pasireiškiančius ar su juo susijusius aspektus. Kol kas negalima tikètis lengvo išsiaiškinimo, būtina toliau gilintis į ūkio ekonominio gyvybingumo žemès ūkyje esmę. 
Todèl, nepretenduojant $\mathfrak{i}$ galutinę ūkio ekonominio gyvybingumo sampratos redakciją, dèl lokalių tyrimo tikslų bus siekiama apibrèžti ūkių ekonominio gyvybingumo vertinimo rodiklius.

\section{Ūkių ekonominị gyvybingumą lemiantys veiksniai}

Analizuojant mokslininkų tyrimus (Scott, 2001; Popelier, 2005; Scott, 2008; Koleda, Lace, 2009; Koleda, Lace, 2010 ir kt.) apie ūkių ekonominị gyvybingumą nustatyta, kad nèra vieningos nuomonès, kokie veiksniai daro ịtaką ekonominiam gyvybingumui. Nuomonių skirtumus neretai lemia individualūs mokslininkų požiūriai ị ekonomines problemas, dèl to skirtingos nuomonès tik dar labiau parodo, kaip svarbu nustatyti ūkių ekonominio gyvybingumo veiksnius.

Ūkių ekonominio gyvybingumo veiksnių problematiką nagrinèjančius mokslinius darbus galima suskirstyti $\mathfrak{i}$ dvi grupes:

- moksliniai darbai, kuriuose nagrinëjamas konkretus ūkio ekonominio gyvybingumo veiksnys (Adelaja, Sullivan, 1989; Adelaja, Derr, Rose, 1998; Agriles, 2001);

- moksliniai darbai, kuriuose ūkio ekonominis gyvybingumas nagrinejjamas kompleksiškai, t. y. analizuojama grupe ekonominio gyvybingumo veiksnių (Scott, 2001; Adelaja, 2005; Popelier, 2005; Adelaja, Peterson, Lake et al., 2007; Scott, 2008).

Mokslinèje literatūroje išskiriama daugybè ūkio ekonomini gyvybingumą lemiančių veiksnių. Jie klasifikuojami ịvairiai. Vieni autoriai veiksnius klasifikuoja pagal daromą poveiki plètrai ir tvarumui (Popelier, 2005; Conner, Colasanti, Ross, 2009), J. B. Whitaker (2009) - pagal pajamų palaikymo priemones. Vienas dažniausiai minimų moksliniuose šaltiniuose klasifikacijų - tai vidiniai ir išoriniai veiksniai (Agriles, 2001; Scott, 2005; Beržinskienè, Virbickaite, 2006; Adelaja, Garcia, Gibson et al., 2007; Fedorčenko, 2008). Ūkio ekonominis gyvybingumas priklauso nuo pirminių išteklių, esančių geografiniame vienete, visumos, o jo rezultatas - nuo vartotojų, besinaudojančių šiais ištekliais, rezultatų.

Analizuojant vidinių veiksnių gausą pastebima, kad dauguma autorių (Argiles, 2001; Scott, 2005; Adelaja, Garcia, Gibson et al., 2007; Fe- dorčenko, 2008) įvardija pelną, inovacijas, informaciją, žinias, kūrybiškumą, žmogiškuosius išteklius, talentą ir pan. Tik M. Singh, A. S. Bhillar, A. S. Joshi (2009) pagrindiniais vidiniais veiksniai laiko ūkio dydi, žemès našumo balą ir vietos ekonomiką. Reikia pastebèti, kad vidiniai veiksniai priklauso tik nuo konkrečiu ūkio rodiklių, o išoriniai yra vienodi visiems toje rinkoje veikiantiems ūkiams, tačiau jų reikšmingumas gali gerokai skirtis. Kitaip tariant, išoriniai veiksniai yra tam tikros sąlygos, kurių ūkis paprastai negali veikti ar pakeisti, tačiau šios sąlygos gali daryti reikšmingą ịtaką ūkių ekonominiams rodikliams. Valstybès politikos ir valdymo struktūros stabilumas teigiamai veikia kiekvieno ūkio ekonomikos plètotę.

Skirtingos teorijos ir modeliai identifikuoja daugybę potencialių veiksnių ūkio ekonominiam gyvybingumui nustatyti. Dažniausiai veiksniai dar yra skirstomi i finansinius ir nefinansinius (Adelaja, Sullivan, 1998; Argiles, 2001; Popelier, 2005; Scott, 2005; Singh, Bhillar, Joshi, 2009).

J. M. Argiles (2001), A. Adelaja (2005), V. Vinciūnienè, J. Rauluškevičienė (2009), M. Singh, A. S. Bhillar, A. S. Joshi (2009) skiria didesni dèmesị nefinansiniams veiksniams, tokiems kaip ūkio dydis, žemès našumo balas, dirbtos valandos ūkyje, ūkininko išsilavinimas, amžius, patirtis ir pan. Ekonominiam gyvybingumui vertinti nemažą itaką turi ūkininko amžius. Empiriniais tyrimais nustatyta (Argiles, 2001; Adelaja, 2005), kad tikimybė patirti nesèkmę su amžiumi didejja. Taip pat teigiama, kad ūkių gyvybingumą veikia ūkininkų išsilavinimas ir nuolatinis jų tobulëjimas. Tačiau pasigendama mokslinių tyrimų, kiek šie veiksniai prisideda prie ūkio ekonominio gyvybingumo didinimo.

Žemès ūkyje vis dar žemas dirbtų valandų rodiklis, kuris parodo nepakankamai profesionalu ūkininkavimą ir ūkių valdymą, ką labai nenoriai pripažįsta patys ūkininkai (vadovai) (Adelaja, 2007). Teigiama, kad kvalifikaciją keliantys ūkininkai priima optimalius sprendimus sėkmingam ūkininkavimui, kurie ir turi įtakos ekonominiam gyvybingumui. Paprastai ūkininkai ir finansiniu institucijų atstovai skaičiuodami naudoja lengvai gaunamus efektyvumo ir produktyvumo rodiklius (Agriles, 2001; Kriuščiukaitienè, Tamošaitienè, Andrikiené, 2010). J. M. Agriles (2001) 
teigia, kad finansiniai veiksniai suteikia išsamesnę informaciją apie ūkio ekonomini gyvybingumą naudojant turto, nuosavybès, išlaidų ir pajamų duomenų informaciją.

J. M. Agriles (2001), A. Balažentis, T. Balažentis (2011) nustatè, kad reikšmingiausi yra finansiniai veiksniai ir juos apibūdinantys rodikliai. Jie greičiausiai ir tiksliausiai atskleidžia ūkių ekonominị gyvybingumą. Tačiau išlieka problema, kuriuos finansinius rodiklius taikyti, kurie rodikliai yra svarbesni. Dažniausiai mokslinèje literatūroje sutinkami finansiniai rodikliai (faktorinès analizès indikatoriai), ūkių ekonominiam gyvybingumui vertinti (1 lentelè).

Ūkio ekonomini gyvybingumą lemiančių veiksnių analizè parodè, kad apskaičiavus finansinius rodiklius, gautų duomenų interpretavimui, naudojami įvairūs statistiniai modeliai. Tačiau nèra sukurto modelio, kuris tiksliai atspindètų ūkių ekonomini gyvybingumą, todèl stengiamasi panaudoti visus šaltinius, kurie galètų padèti ịvertinti ùkių ekonominị gyvybingumą.

1 lentelè. Ūkio ekonominị gyvybingumą lemiančius veiksnius apibūdinantys finansiniai rodikliai (Scott, 2001; Scott, 2008)

Table 1. Financial indicators describing the factors conditioning the economical viability in agriculture (Scott, 2001; Scott, 2008)

\begin{tabular}{|c|c|c|}
\hline $\begin{array}{l}\text { Rodikliai }\left(\mathrm{ROD}_{\mathrm{i}}\right) \\
\text { Indicators }\left(\mathrm{IND}_{i}\right)\end{array}$ & 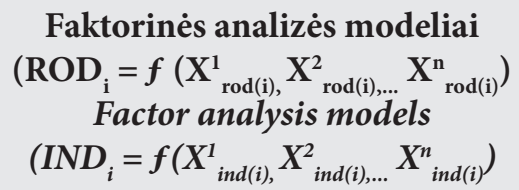 & $\begin{array}{c}\text { Faktorių apibūdinimas }\left(\mathrm{X}^{\mathrm{j}}{ }_{\operatorname{rod}(\mathrm{i})}\right) \\
\text { Description of factors }\left(\mathrm{X}_{\operatorname{ind}(i)}\right)\end{array}$ \\
\hline
\end{tabular}

BPR - bendroji produkcija / Total output GS - gamybos subsidijos / Subsidies excl. investm. ŪŠD - ùkininko ir šeimos narių atlygis / Value of unpaid labour

Kapitalo grąža / Re- $\quad((\mathrm{BPR}+\mathrm{GS})-\mathrm{U} S ̌ \mathrm{D}) /((\mathrm{TT}+\mathrm{IT})-$ turn on investment (TS + IS))
TT - trumpalaikis turtas / Current assets IT - ilgalaikis turtas / Fixed assets

TS - trumpalaike skola / Short-term debt

IS - ilgalaikè skola / Long-term debt

VIDSUV - vidinis suvartojimas / Intermediate consumption

Sąnaudų ir pajamų santykis / Expense to income ratio
(VID-

$\mathrm{SUV}+\mathrm{NUS}+\mathrm{KTS}) /(\mathrm{BPR}+\mathrm{GS})$
NUS - nusidèvejjimas / Depreciation

KTS - kitos sąnaudos / External factors

BPR - bendroji produkcija / Total output GS - gamybos subsidijos / Subsidies excl. investm.

TS - trumpalaikè skola / /Short-term debt

IS - ilgalaikè skola / Long-term debt

İsipareigojimų ir bendrojo pelno santykis / Debt to net income ratio

$$
(\mathrm{TS}+\mathrm{IS}) /((\mathrm{BPR}+\mathrm{GS})-(\mathrm{VID}-
$$
$\mathrm{SUV}+\mathrm{NUS}+\mathrm{KTS}))$
BPR - bendroji produkcija / Total output GS - gamybos subsidijos / Subsidies excl. investm.

VIDSUV - vidinis suvartojimas / (Intermediate consumption)

NUS - nusidèvejimas / Depreciation

KTS - kitos sąnaudos / External factors
GS - gamybos subsidijos / Subsidies excl. investm. BPR - bendroji produkcija / Total output

VIDSUV - vidinis suvartojimas / Intermediate consumption

NUS - nusidèvejimas / Depreciation KTS - kitos sąnaudos / External factors

$$
\text { ency ratio }
$$

Pardavimu pel ningumas / Profitability of sales
$(\mathrm{Q} * \mathrm{~K}-\mathrm{VID}$ -

SUV - NUS - KTS $) /\left(Q^{\star} K\right)$
$\mathrm{Q}$ - pardavimų apimtys / Sales volume, units $\mathrm{K}$ - kaina / Price 


\begin{tabular}{|c|c|c|}
\hline \multicolumn{3}{|l|}{$\begin{array}{l}\text { 1 lentelè (tęsinys) } \\
\text { Table } 1 \text { (continued) }\end{array}$} \\
\hline $\begin{array}{l}\text { Rodikliai }\left(\mathrm{ROD}_{\mathrm{i}}\right) \\
\text { Indicators }\left(I N D_{i}\right)\end{array}$ & 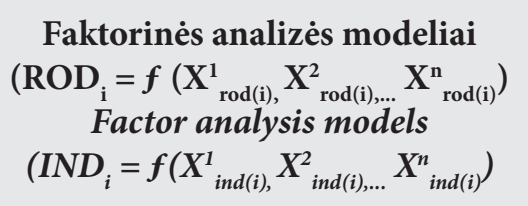 & $\begin{array}{c}\text { Faktorių apibūdinimas }\left(\mathrm{X}^{\mathrm{j}}{ }_{\text {rod(i }}\right) \\
\text { Description of factors }\left(X_{\text {ind(i }}^{j}\right)\end{array}$ \\
\hline $\begin{array}{l}\text { Skolos ir nuo- } \\
\text { savo kapitalo } \\
\text { santykis / Debt to } \\
\text { equity ratio }\end{array}$ & $\begin{array}{c}((\mathrm{S} / \mathrm{T}) /(\mathrm{IT} / \mathrm{T}) /(\mathrm{TT} / \\
\mathrm{IT}) /(\overline{\mathrm{USS}} \mathrm{D} / \mathrm{TT}))^{*}(\overline{\mathrm{USS}} \mathrm{D} / \mathrm{NK})\end{array}$ & $\begin{array}{c}\text { S - skolos / Debt } \\
\text { T - turtas / Assets } \\
\text { TT - trumpalaikis turtas / Current assets } \\
\text { IT - ilgalaikis turtas / Fixed assets } \\
\text { NK - nuosavas kapitalas / Equity } \\
\text { ŪŠD - ūkininko ir šeimos narių atlygis / Value of } \\
\text { unpaid labour }\end{array}$ \\
\hline $\begin{array}{l}\text { Palūkanu padengi- } \\
\text { mo rodiklis } \\
\text { Percentage coverage } \\
\text { ratio }\end{array}$ & $\mathrm{BP} / \mathrm{P}$ & $\begin{array}{l}\text { BP - bendrasis pelnas / Profit } \\
\text { P - palūkanos / Interest charges }\end{array}$ \\
\hline $\begin{array}{l}\text { Turto pelningu- } \\
\text { mas / Profitability } \\
\quad \text { of assets }\end{array}$ & $\begin{array}{c}((\mathrm{BPR} /(\mathrm{VIDSUV}+\mathrm{NUS}+\mathrm{KTS})) \\
-\mathrm{A})^{*}(\mathrm{TT} / \mathrm{T})^{\star}(\mathrm{A} / \mathrm{TT})^{\star}(\mathrm{VIDSUV}+ \\
\mathrm{NUS}+\mathrm{KTS} / \mathrm{A})\end{array}$ & $\begin{array}{c}\text { BPR - bendroji produkcija / Total output } \\
\text { VIDSUV - vidinis suvartojimas / Intermediate } \\
\text { consumption } \\
\text { NUS - nusidèvejimas / Depreciation } \\
\text { KTS - kitos sąnaudos / External factors } \\
\text { A - atsargos / Inventories } \\
\text { TT - trumpalaikis turtas / Current assets } \\
\text { T - turtas / Assets }\end{array}$ \\
\hline
\end{tabular}

Autorių nuomone, nefinansiniai veiksniai nesuteikia tiek svarbios informacijos apie ūkių ekonominio gyvybingumo būklę, ir kad itin svarbios yra ūkio finansinès ataskaitos. Jos parodo ūkių vidinių rodiklių ịvertinimą. Autorès pritaria F. Liou (2008), kad finansinių santykinių rodiklių taikymas galbūt būtų paprasčiausias būdas ūkio ekonominiam gyvybingumui vertinti. Tačiau išlieka problema, kuriuos finansinius rodiklius taikyti, kurie rodikliai yra svarbesni, kaip vertinti ju reikšmes. Šiuo tyrimu siekiama patvirtinti arba paneigti hipotezę, kad svarbiausi rodikliai ūkio ekonominiam gyvybingumui vertinti yra kapitalo grąža, skolų ir bendrojo pelno santykis, sąnaudų ir pajamų santykis, gamybos subsidijų ir bendrojo pelno santykis. Siekiant ịvertinti šių rodiklių svarbą, bus atliktas tyrimas Lietuvos ùkininkų ūkiuose.

\section{Lietuvos ūkininkų ūkių ekonominio gyvybingumo tyrimas}

Pagrindinè informacija ūkio gyvybingumui įvertinti yra gaunama iš ūkininko ūkio balanso ir pelno (nuostolių) ataskaitos, tačiau dalį duomenų reikia paimti ir iš Didžiosios knygos sąskaitų. Nemažai informacijos apie vykdomos veiklos rezultatus pateikiama pinigu srautų ataskaitoje. Norint teisingai interpretuoti apskaičiuotus rodiklius, būtina nustatyti jų kitimą laike bei palyginti su kitų žemès ūkio veiklos subjektų rodikliais. Tai reiškia, kad ūkiuose finansinių duomenų kaupimas yra būtina priemonè, nurodanti ūkio ekonominę gyvybingumo būklę, jo stipriąsias ir silpnąsias puses.

Finansiniai veiksniai ir jų rodikliai žymiai greičiau pateikia informaciją apie ūkio ekonomini gyvybingumą, nes didejantys ūkių finansiniai ịsipa- 
reigojimai, menkas grynojo pelno gavimas ir turto pelningumas yra labai pažeidžiami nuo dažnų atsitiktinių padarinių žemès ūkyje, kurie priveda prie mažejančių pajamų. Ūkio pajamų mažejimui taip pat turi ịtakos krentančios kainos ir gamtinès sąlygos, kurios paveikia gamybą, pajamas ir grynuosius pinigu srautus (Agriles, 2001).

Pateikti rodikliai (2 lentelè), kurie mokslinèje literatūroje nurodomi dažniausiai ir rekomenduojami kaip geriausiai atspindintys ūkių ekonominị gyvybingumą (Adelaja et al., 1998; Argiles, 2001; Scott, 2001; Popelier, 2005; Scott, 2005; Adelaja, 2007; Singh, Bhillar, Joshi, 2009; Vrolijk, Bont,
Blokland et al., 2010; Scotti, Bergmann, Henke et al., 2011 ir kt.). Kanadoje jau nuo $1971 \mathrm{~m}$. yra atliekami moksliniai tyrimai ūkių ekonominiam gyvybingumui nustatyti (Scott, 2001; 2008). Pirmasis empirinis tyrimas buvo atliktas $2001 \mathrm{~m}$. Tyrimo metu buvo pateiktos gyvybingumo ribos.

Remiantis Kanadoje atlikto tyrimo metodika, autorès apskaičiavo Lietuvos ūkininkų ūkių ekonomini gyvybingumą pagal Lietuvos respondentinių ūkininkų ūkių duomenis. Vienas iš svarbiausių gyvybingumo rodiklių yra kapitalo grąža. Lyginant 2003-2010 m. laikotarpio rodiklius, mažiausia kapitalo grąža buvo 2009 m. (1 pav.).

2 lentelè. Ekonominio gyvybingumo rodikliai ir jų ribos (Scott, 2001)

Table 2. The indicators of the economic viability and their limits (Scott, 2001)

\begin{tabular}{cc}
\hline Rodikliai / Indicators & Gyvybingumo riba / Viability Threshold \\
\hline Kapitalo grąža \% / Return on investment, \% & Daugiau kaip 5\% / More than 5\% \\
\hline Sąnaudų ir pajamų santykis \% / Expense to income ratio, \% & Mažiau kaip 80 \% / Less than 80\% \\
\hline Skolų ir bendrojo pelno santykis \% / Debt to net income ratio, \% & Mažiau kaip 600 \% / Less than 600\% \\
\hline $\begin{array}{c}\text { Gamybos subsidijų ir bendrojo pelno santykis \% / Direct pay- } \\
\text { ments to producers and dependency ratio, \% }\end{array}$ & Mažiau kaip 20 \% / Less than 20\% \\
\hline
\end{tabular}

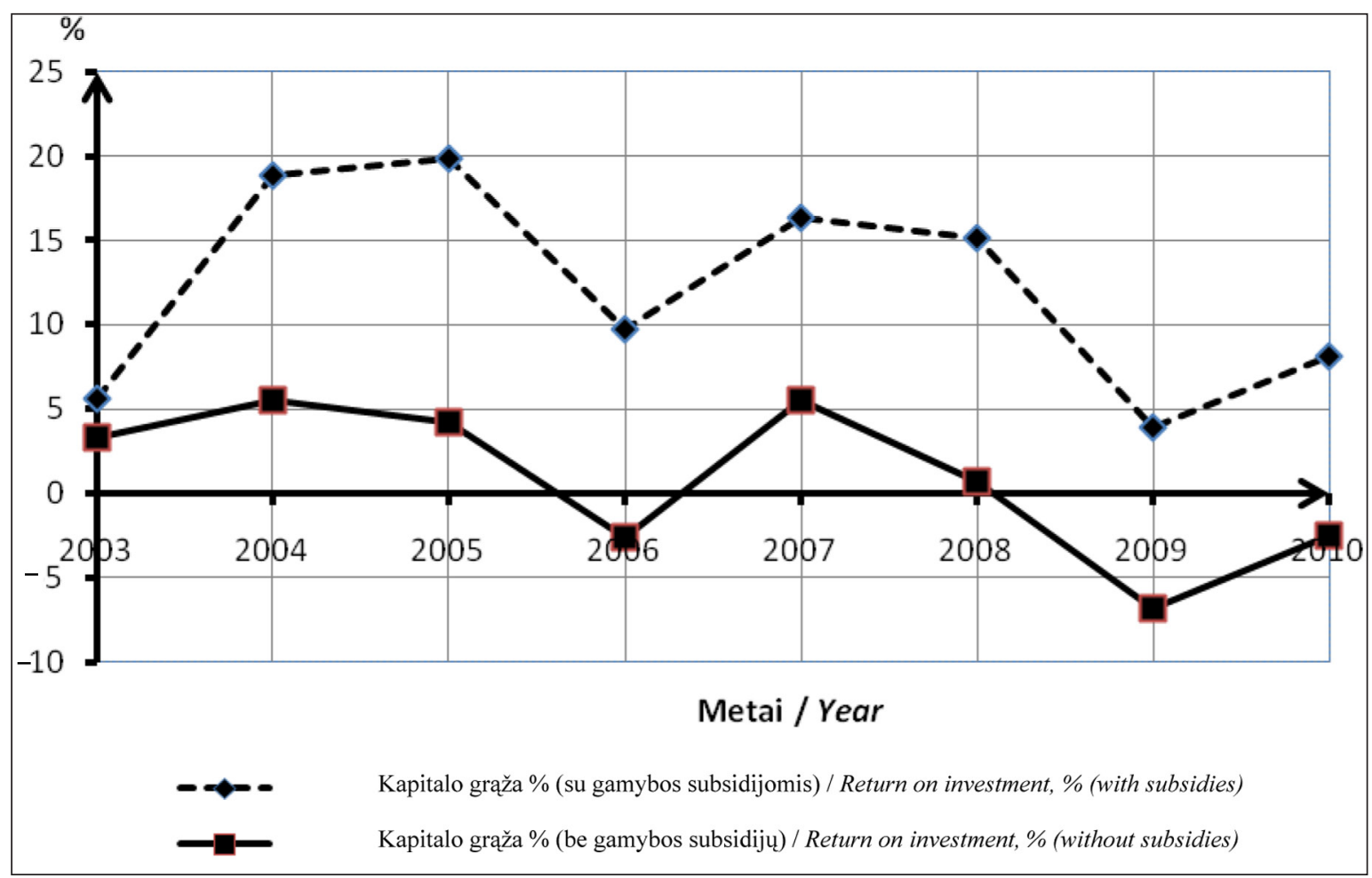

1 pav. Kapitalo grąža Lietuvos ūkininkų ūkiuose 2003-2010 m. \%

Fig. 1. Return on investment in the Lithuanian farmers' farms, 2003-2010, \% 
2009 m. - 3,90 \% (su gamybos subsidijomis), o be gamybos subsidijų - neigiama (6,83 \%). Tačiau gavus finansinę paramą tiek iš valstybès ir ES, kapitalo grąža visais metais buvo daugiau kaip 5 \% nustatytos gyvybingumo ribos, išskyrus 2009 m. Šiuo atveju yra dirbtinai palaikomas ūkių ekonominis gyvybingumas, nes subsidijas galima vertinti kaip santykinai laikinas. Svarbu, kad subsidijos turètų ilgalaikị išliekamaji, o ne trumpalaiki poveiki ūkio ekonomikos pletotei. C. Popelier (2005) teigia, kad kapitalo grąža mažeja visame pasaulyje todèl, kad nèra ilgalaikès žemès ūkio tvarumo koncepcijos, kuri užtikrintų ilgalaikị stabilumą ir gyvybingumą žemès ūkyje.

Kiekvieno ūkininko ūkio pagrindinis tikslas - ne tik pasigaminti šeimai reikalingą žemès ūkio ir maisto produktų kiekį, bet ir gauti pakankamai pajamų, kad jos garantuotų normalų šeimos gyvenimo lygi bei leistų toliau plètoti numatytą veiklą. Reikia pastebèti, kad Lietuvoje ūkininkų ūkių pajamos per nagrinëjamą laikotarpị didẻjo, o didžiausią ịtaką turëjo gaunamos gamybos subsidijos.
Išlaidų ir pajamų santykis per nagrinejjamą laikotarpi mažai kito (2 pav.). Lyginant $2004 \mathrm{~m}$. su 2010 m. - padidejo 7,33 \%, o 2003 m. su 2010 m. - sumažèjo 6,8 \%. Lietuvoje ūkininku ūkiai neviršijo $80 \%$ gyvybingumo ribos, nustatytos J. Scott (2001) tyrimu. Nežymus didejjimas rodo, kad kainos mokamos gamintojams už produkciją (paslaugas) yra nepakankamos, palyginti su didèjančiomis išlaidomis. Nors bendrasis ūkio pelnas Lietuvoje didèjo (Žemès ūkio respondentinių..., 2004, 2006, Ūkio veiklos..., 2008, 2010), tačiau visų ùkininkų ùkių gerokai padidejo ir įsiskolinimai: 2004 m., palyginti su 2010 m., net iki $140 \%$ (2 pav.). J. Scott (2001) teigia, kad skolos ir bendrojo pelno santykis neturètų viršyti $600 \%$, kad ūkininkai savo skolos ịsipareigojimus padengtų laiku, per sutartyse nurodytus terminus. Tai reiškia, kad Lietuvos ūkininkų skolos padengimo rodiklis yra aukštas ir įsiskolinimai padengiami laiku.

Lietuvai įstojus $\mathfrak{i}$ ES, geresnès tapo ūkininkų ūkių apsirūpinimo finansiniais ištekliais galimybès,

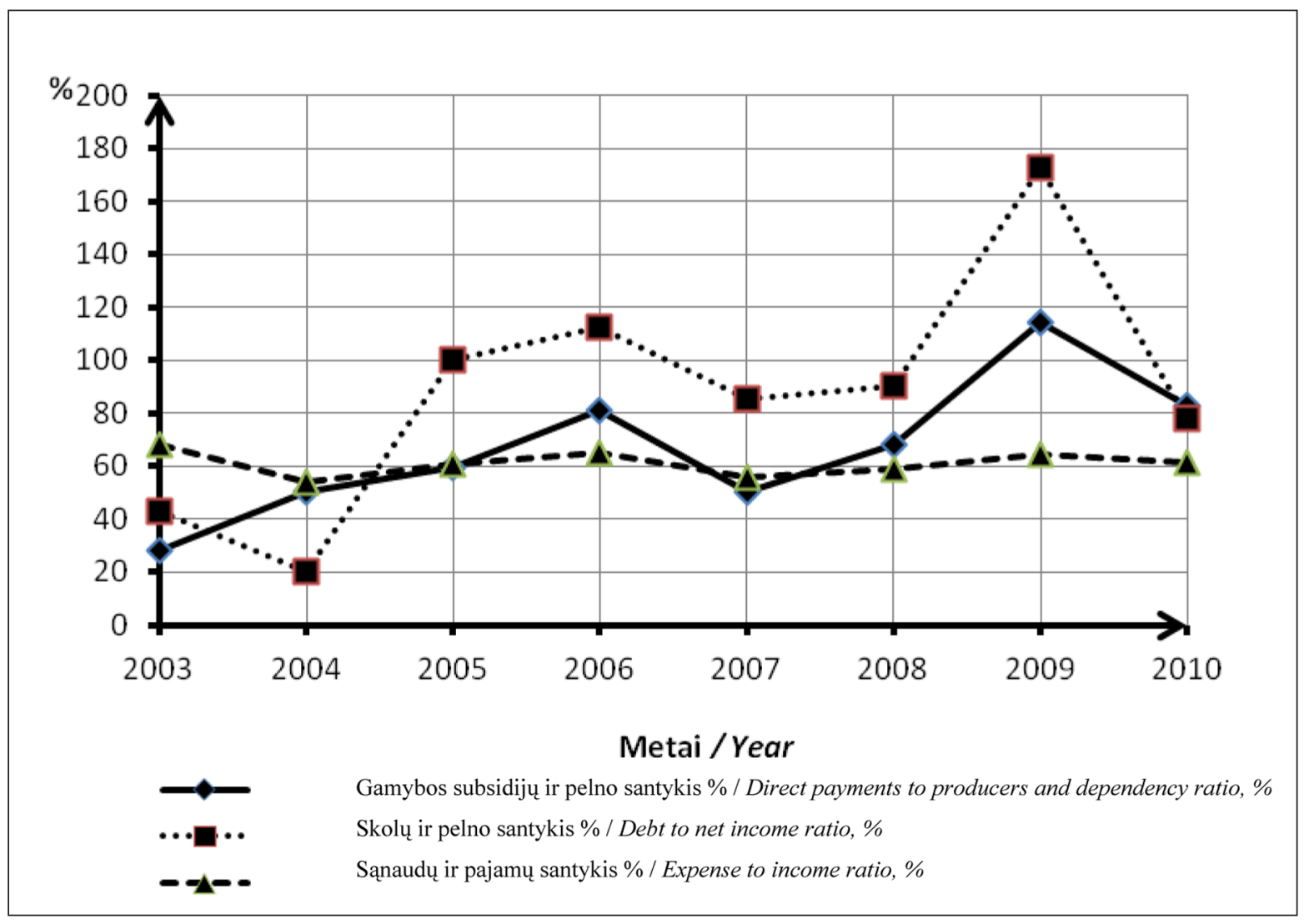

2 pav. Ekonominio gyvybingumo rodikliai Lietuvos ūkininkų ūkiuose 2003-2010 m. \% Fig. 2. Viability indicators in Lithuanian farmers' farms, 2003-2010, \% 
nes buvo modernizuojamos gamybos technologijos, ūkiai pasiekè geresnių rezultatų, kartu su finansine parama augo ir žemès ūkio produktų gamintojų bendroji produkcija. $2003 \mathrm{~m}$. gamybos subsidijų ir bendrojo pelno santykis vidutiniškai svyravo nuo $17,61 \%$ iki $48,42 \%$, o 2009 m. nuo 79,49 \% iki 168,55 \%. 2009 m. gyvybingumo riba viršijo nustatytą net 8 kartus (rekomenduojama mažiau kaip $20 \%$ ) (3 lentelè). Tačiau reikia pastebèti, kad tam įtakos turejo sumažejęs bendrasis pelnas bei gaunamos didelès gamybos subsidijos (tiesioginès ir kompensacinès išmokos) iš valstybès bei ES. Svarbu, kad subsidijos sukurtų, palaikytų ir stiprintų ūkio ekonomini gyvybingumą ilguoju laikotarpiu, o nebūtų pajamų palaikymo priemonė tik trumpą laiką.

Atlikus empirini tyrimą nustatyta, kad svarbiausi rodikliai ūkio ekonominiam gyvybingumui vertinti yra kapitalo grąža, skolų ir bendrojo pelno santykis, sąnaudų ir pajamų santykis, gamybos subsidiju ir bendrojo pelno santykis (4 lentelè). Šiuos rodiklius lèmé ryšio stiprumo nustatymas porinès koreliacijos metodu. Tai iš dalies byloja apie rodiklių tinkamumą priklausyti ekonometriniam modeliui vertinant ūkių ekonominị gyvybingumą.

Apibendrinant galima teigti, kad ūkiai Lietuvoje gyvybingi tik dèl gamybos subsidijų, nes šis rodiklis stipriai nutolęs nuo gyvybingumo ribos. Visi kiti rodikliai yra žemiau nustatytos ribos (3 lentelè). Ūkininkai turi pasirinkti tinkamą valdymo strategiją, optimalius sprendimo rezultatus ir be gamybos subsidiju gerinti žemès ūkio veiklos rezultatus bei sukurti ùkio pajamas ateičiai. Tačiau reikia pastebèti, kad bet koks, nors ir menkas, bendrasis ūkių pelnas be subsidijų atspindètų priimtą efektyvų sprendimą ir ūkio gyvybingumą ateityje.

Remiantis mokslininkų (Agriles, 2001; Scott, 2001) atliktais tyrimais galima daryti išvadą, kad pirminiai ūkio ekonominio gyvybingumo požymiai pastebimi finansinèse ataskaitose. Šiuo metu, kol dar nèra sukurta tinkamiausio ūkio ekonominio gyvybingumo vertinimo modelio, stengiamasi panaudoti visus šaltinius, kurie gali ịvertinti ūkio ekonominị gyvybingumą. Tam, kad iš daugelio siūlomų rodiklių atrinktų geriausiai įrodančius ūkio ekonomini gyvybingumą, mokslininkai empiriniuose modeliuose dažniausiai taiko statistinius metodus. Jie, ieškodami priežasčių, vertina ūkio ekonomini gyvybingumą, bando pritaikyti jau sukurtus modelius, juos tobulina arba ieško naujų ūkio gyvybingumo vertinimo modelių ar algoritmų, nes nèra sukurta vieno modelio, kuri būtų galima pritaikyti.

Autorès, norèdamos issitikinti J. Scott (2001; 2008) tyrimuose naudojamų finansinių rodiklių patikimumu vertinant ūkių ekonomini gyvybingumą, atliko koreliacinę analizę, nustatydamos veiksnių ryšio stiprumą ir reikšmingumą finansiniams rodikliams ūkių ekonominiam gyvybingumui vertinti koreliacinès matricos pagalba.

3 lentelè. Ekonominio gyvybingumo rodikliai ir jų ribos Lietuvos ūkininkų ùkiuose 2003-2010 m. \%

Table 3. The economical viability indicators and their margins in Lithuanian farms in 2003-2010, \%

\begin{tabular}{|c|c|c|c|c|c|c|c|c|c|}
\hline \multirow[b]{2}{*}{ Rodikliai / Indicators } & \multirow{2}{*}{$\begin{array}{l}\text { Gyvybingu- } \\
\text { mo ribos \% } \\
\text { Viability } \\
\text { threshold, \% }\end{array}$} & \multicolumn{8}{|c|}{ Metai / Year } \\
\hline & & 2003 & 2004 & 2005 & 2006 & 2007 & 2008 & 2009 & 2010 \\
\hline $\begin{array}{c}\text { Kapitalo grąža \% } \\
\text { Return on investment, \% }\end{array}$ & $>5$ & 5,56 & 18,83 & 19,86 & 9,72 & 16,33 & 15,13 & 3,90 & 8,14 \\
\hline $\begin{array}{c}\text { Sąnaudų ir bendrujuc } \\
\text { pajamų santykis \% } \\
\text { Expense to income ratio, \% }\end{array}$ & $<80$ & 68,35 & 54,22 & 60,82 & 64,95 & 56,07 & 58,79 & 64,52 & 61,55 \\
\hline $\begin{array}{l}\text { Skolų ir bendrojo pelno } \\
\text { santykis \% / Debt to net } \\
\text { income ratio, \% }\end{array}$ & $<600$ & 43,27 & 20,13 & 99,92 & 112,49 & 85,70 & 90,59 & 172,71 & 78,26 \\
\hline $\begin{array}{l}\text { Gamybos subsidijų ir ben- } \\
\text { drojo pelno santykis \% } \\
\text { Direct payments to produ- } \\
\text { cers and dependency ratio, } \%\end{array}$ & $<20$ & 28,46 & 50,65 & 59,51 & 81,32 & 50,06 & 68,15 & 114,44 & 82,89 \\
\hline
\end{tabular}


4 lentelè. Finansinių rodiklių ryšio stiprumo nustatymas vertinant ūkių ekonominị gyvybingumą

Table 4. Estimation of relations strength of financial indicators for evaluating the farms viability

\begin{tabular}{|c|c|c|c|c|c|c|c|}
\hline Kintamieji / Variables & 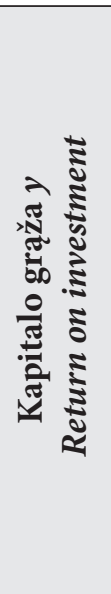 & 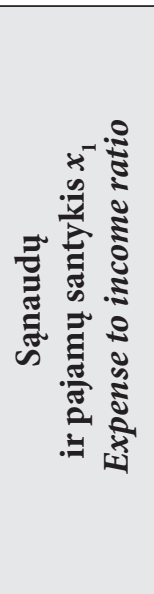 & 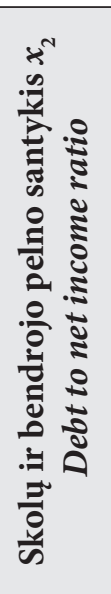 & 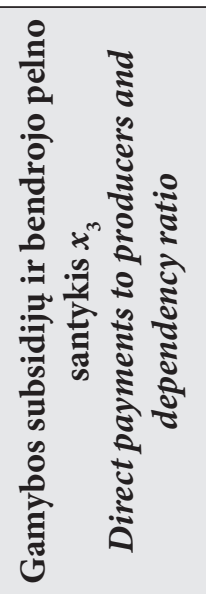 & 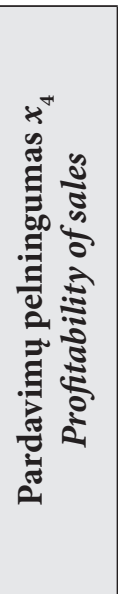 & 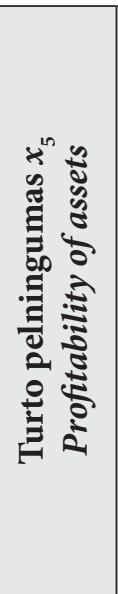 & 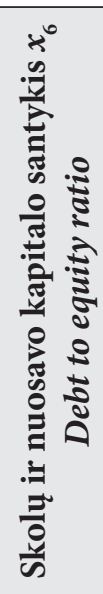 \\
\hline $\begin{array}{c}\text { Kapitalo grąža } y \\
\text { Return on investment }\end{array}$ & 1,00 & $-0,75$ & $-0,23$ & $-0,56$ & 0,75 & 0,90 & 0,28 \\
\hline $\begin{array}{c}\text { Sąnaudų ir pajamų santykis } x_{1} \\
\text { Expense to income ratio }\end{array}$ & $-0,75$ & 1,00 & 0,61 & 0,46 & $-1,00$ & $-0,89$ & 0,20 \\
\hline $\begin{array}{c}\text { Skolų ir bendrojo pelno santykis } x_{2} \\
\text { Debt to net income ratio }\end{array}$ & $-0,23$ & 0,61 & 1,00 & 0,47 & $-0,60$ & $-0,55$ & 0,78 \\
\hline $\begin{array}{l}\text { Gamybos subsidiju ir bendrojo } \\
\text { pelno santykis } x_{3} \\
\text { Direct payments to producers and } \\
\text { dependency ratio }\end{array}$ & $-0,56$ & 0,46 & 0,47 & 1,00 & $-0,44$ & $-0,59$ & 0,08 \\
\hline $\begin{array}{c}\text { Pardavimų pelningumas } x_{4} \\
\text { Profitability of sales }\end{array}$ & 0,75 & $-1,0$ & $-0,61$ & $-0,46$ & 1,00 & 0,89 & $-0,19$ \\
\hline $\begin{array}{c}\text { Turto pelningumas } x_{5} \\
\text { Profitability of assets }\end{array}$ & 0,90 & $-0,89$ & $-0,55$ & $-0,59$ & 0,89 & 1,00 & $-0,07$ \\
\hline $\begin{array}{c}\text { Skolų ir nuosavo kapitalo santykis } \\
\text { x6 / Debt to equity ratio }\end{array}$ & 0,28 & 0,20 & 0,78 & 0,08 & $-0,19$ & $-0,07$ & 1,00 \\
\hline
\end{tabular}

4 lentelëje pateikta porinių koreliacijų tarp kapitalo grąžos $(y)$ ir sąnaudų bei pajamų santykio $\left(x_{1}\right)$, skolų ir bendrojo pelno santykio, gamybos subsidiju ir bendrojo pelno santykio ir t. t. rodiklių matrica. Paryškinti skaičiai žymi patikimas ir statiškai reikšmingas koreliacijas. Finansinių rodiklių porinès koreliacijos iš dalies byloja, kad rodikliai yra tinkami priklausyti ekonometriniam modeliui vertinant ūkių ekonominị gyvybingumą, išskyrus koreliacijos koeficientus su kintamuoju $\mathrm{X}_{6}$ (skolų ir nuosavo kapitalo santykis). Reikia pastebèti, kad atliktame J. Scott (2001) tyrime paminèti pirmi keturi finansiniai rodikliai yra įtraukti kaip pagrindiniai, vertinantys ùkių ekonominị gyvybingumą (2 lentelè). Kituose moksliniuose tyrimuose (Agriles, 2001; Popelier, 2005; Conner, 2009) rekomenduoja skaičiuoti pardavimų ir turto pelningumo bei finansinio sverto rodiklius. Pardavimo ir turto pelningumo poriniai rodiklių ryšiai yra pakankamai stiprūs, silpnesni yra tik skolų ir nuosavo kapitalo porų rodikliai.

Autorès, atlikusios finansinių rodiklių tinkamumo analizę vertinant ūkio ekonomini gyvybingumą, pasirinko pirmus keturis rodiklius ir išsamiau juos analizavo. Remiantis nustatytais veiksniais (1 lentelè), turinčiais ịtakos finansiniams rodikliams vertinant ūkių ekonominị gyvybingumą, pasitelkta $\mathfrak{i}$ pagalbą porinès ir dalinès koreliacijos metodai.

Porinès koreliacijos pagalba nustatytas veiksnių ryšio stiprumas kapitalo grąžos rodikliui. Pakankamai stiprūs ryšiai yra su ūkininko ir šeimos narių atlygiu, ilgalaikiu turtu, nusidèvejimu ir kitomis sąnaudomis. Porinès koreliacijos koeficientai ne visuomet yra patikimi. Patikimesnès charakteristikos yra dalinès koreliacijos rodikliai. Pagal dalinès koreliacijos rodiklius, vieni reikšmingiausių veiksnių yra bendroji produkcija ir 
gamybos subsidijos (5 lentelè). Tai pagrindiniai veiksniai, kurie teigiamai veikia ūkiu ekonominio gyvybingumo rodiklių reikšmes. Gamybos subsidijos priklauso nuo valstybès politikos, o bendroji produkcija - nuo kainos ir faktinių pardavimo apimčių. Tai veiksniai, kurie lemia ūkių ekonominio gyvybingumo rodiklius. Kaina ir pardavimo apimtys šiame tyrime nebuvo analizuotos, tačiau autorès ateityje planuoja tęsti mokslinius tyrimus.

Pagal porinę koreliaciją apskaičiuoti reikšminiai koeficientai yra visų rūšių sąnaudos. Tai leidžia daryti išvadą, kad didesnę įtaką turi sąnaudos nei pajamos. Tačiau ryšys tarp sąnaudų yra pakankamai stiprus, išskyrus tik kitas sąnaudas, kurios yra dažniausiai veikiamos išorinių veiksnių. Reikia pastebèti, kad porine koreliacija iškreipia ryši tarp sąnaudų ir pajamų santykio rodiklio veiksnių, nes dalinès koreliacijos koeficientai parodo, kad bendrosios produkcijos ir gamybos subsidiju veiksniai turi gerokai didesnès ịtakos nei sąnaudos. Atlikus dalinę koreliaciją (6 lentelè) pastebèta, kad visi veiksniai yra reikšmingi ūkių ekonominiam gyvybingumui vertinti.

Porinè koreliacija parodė, kad įsipareigojimų ir bendrojo pelno santykio rodiklio veiksnių ryšio stiprumas yra tarp skolų, sąnaudų ir bendrosios produkcijos, o nereikšmingas veiksnys yra gamybos subsidijos. Tačiau atlikus dalinę koreliaciją paaiškejjo, kad gamybos subsidijos yra veiksnys, lemiantis issipareigojimų ir bendrojo pelno santykio rodiklį. Nereikšmingas veiksnys yra kitos veiklos sąnaudos (7 lentelè).

Pagal porinę koreliaciją ne visų nagrinėjamų veiksnių ryšys yra stiprus, tačiau pateikti veiksniai (8 lentelè) yra reikšmingi skaičiuojant dalinę

5 lentelè. Veiksnių reikšmingumo nustatymas kapitalo grąžos rodikliui vertinant ūkių ekonominị gyvybingumą Table 5. Estimation of significance of factors for the return investment indicator in evaluating the farms viability

\begin{tabular}{|c|c|c|c|c|}
\hline \multirow[t]{2}{*}{ Veiksniai / Factors } & \multicolumn{4}{|c|}{$\begin{array}{c}\text { Kintamujų sąveikos ir jos patikimumo rodikliai } \\
\text { The indicators of variables interaction and its } \\
\text { dependability }\end{array}$} \\
\hline & $r_{y x}$ & $\boldsymbol{R}_{\mathrm{dal}}$ & $p$ & $t(69)$ \\
\hline Gamybos subsidijos / Subsidies excl. investm. & $-0,18$ & 0,75 & 0,00 & $-5,18$ \\
\hline Bendroji produkcija / Total output & 0,19 & 0,91 & 0,00 & 22,83 \\
\hline Ukininko ir šeimos narių atlygis / Value of unpaid labour & $-0,56$ & $-0,54$ & $\mathbf{0 , 0 0}$ & $-6,29$ \\
\hline Trumpalaikis turtas / Current assets & $-0,14$ & $-0,39$ & 0,00 & $-3,53$ \\
\hline Ilgalaikis turtas / Fixed assets & $-0,38$ & 0,05 & 0,63 & 0,48 \\
\hline Trumpalaikès skolos / Short-term debt & 0,20 & 0,09 & 0,47 & 0,72 \\
\hline Ilgalaikès skolos / Long-term debt & 0,09 & $-0,07$ & 0,56 & $-0,59$ \\
\hline Nusidèvèjimas / Depreciation & $-0,51$ & $-0,59$ & 0,00 & $-6,09$ \\
\hline Vidinis suvartojimas / Intermediate consumption & $-0,15$ & $-0,73$ & 0,00 & $-8,85$ \\
\hline Kitos sąnaudos / External factors & 0,23 & $-0,01$ & 0,92 & $-0,10$ \\
\hline
\end{tabular}

6 lentelè. Veiksnių reikšmingumo nustatymas sąnaudų ir pajamų santykio rodikliui vertinant ūkių ekonominị gyvybingumą

Ta b le 6. Estimation of significance of factors for the expense to income ratio indicator in evaluating the farms viability

\begin{tabular}{|c|c|c|c|c|}
\hline \multirow[t]{2}{*}{ Veiksniai / Factors } & \multicolumn{4}{|c|}{$\begin{array}{l}\text { Kintamujjų sąveikos ir jos patikimumo rodikliai } \\
\text { The indicators of variables interaction and its dependability }\end{array}$} \\
\hline & $\boldsymbol{r}_{y x}$ & $\boldsymbol{R}_{\mathrm{dal}}$ & $p$ & $t(74)$ \\
\hline Bendroji produkcija / Total output & 0,11 & $-0,94$ & 0,00 & $-23,14$ \\
\hline Gamybos subsidijos / Subsidies excl. investm. & $-0,05$ & $-0,88$ & 0,00 & $-16,27$ \\
\hline Nusidèvejjimas / Depreciation & 0,46 & 0,80 & 0,00 & 11,52 \\
\hline Vidinis suvartojimas / Intermediate consumption & 0,45 & 0,85 & 0,00 & 14,06 \\
\hline Kitos sąnaudos / External factors & 0,29 & 0,28 & 0,01 & 2,51 \\
\hline
\end{tabular}


7 lentelè. Veiksnių reikšmingumo nustatymas ịsipareigojimų ir bendrojo pelno santykio rodikliui vertinant ūkių ekonominị gyvybingumą

Table 7. Estimation of significance of factors for the debt to net income ratio indicator in evaluating the farms viability

\begin{tabular}{|c|c|c|c|c|}
\hline \multirow[t]{2}{*}{ Veiksniai / Factors } & \multicolumn{4}{|c|}{$\begin{array}{l}\text { Kintamujų sąveikos ir jos patikimumo rodikliai } \\
\text { The indicators of variables interaction and its dependability }\end{array}$} \\
\hline & $r_{y x}$ & $\boldsymbol{R}_{\mathrm{dal}}$ & $p$ & $\mathrm{t}(72)$ \\
\hline Gamybos subsidijos / Subsidies excl. investm. & 0,20 & $-0,56$ & 0,00 & $-5,80$ \\
\hline Bendroji produkcija / Total output & 0,33 & $-0,84$ & 0,00 & $-12,93$ \\
\hline Trumpalaikè skola / Short-term debt & 0,73 & 0,60 & 0,00 & 6,38 \\
\hline Ilgalaikè skola / Long-term debt & 0,74 & 0,77 & 0,00 & 10,11 \\
\hline Nusidèvejjimas / Depreciation & 0,41 & 0,41 & 0,00 & 3,81 \\
\hline Vidinis suvartojimas / Intermediate consumption & 0,64 & 0,55 & 0,00 & 5,58 \\
\hline Kitos sąnaudos / External factors & 0,71 & $-0,08$ & 0,51 & $-0,67$ \\
\hline
\end{tabular}

8 lentelè. Veiksnių reikšmingumo nustatymas gamybos subsidijų ir bendrojo pelno santykio rodikliui vertinant ūkių ekonominị gyvybingumą

Table 8. Estimation of significance of factors for the direct payments to producers and dependency ratio indicator in evaluating the farms viability

\begin{tabular}{c|c|c|c|c}
\hline \multirow{2}{*}{ Veiksniai / Factors } & \multicolumn{4}{|c}{$\begin{array}{c}\text { Kintamuju sąveikos ir jos patikimumo rodikliai } \\
\text { The indicators of variables interaction and its dependability }\end{array}$} \\
\cline { 2 - 5 } & $\boldsymbol{r}_{\boldsymbol{y x}}$ & $\boldsymbol{R}_{\mathrm{dal}}$ & $\boldsymbol{p}$ & $\boldsymbol{t}(\mathbf{7 4 )}$ \\
\hline Gamybos subsidijos / Subsidies excl. investm. & 0,74 & 0,68 & 0,00 & 8,09 \\
\hline Bendroji produkcija / Total output & $-0,29$ & $-0,88$ & 0,00 & $-15,80$ \\
\hline Nusidevejimas / Depreciation & 0,47 & 0,57 & 0,00 & 5,97 \\
\hline Vidinis suvartojimas / Intermediate consumption & 0,13 & $\mathbf{0 , 6 1}$ & $\mathbf{0 , 0 0}$ & $\mathbf{6 , 5 9}$ \\
\hline Kitos sąnaudos / External factors & 0,09 & $\mathbf{0 , 2 4}$ & $\mathbf{0 , 0 4}$ & $\mathbf{2 , 0 9}$ \\
\hline
\end{tabular}

koreliaciją. Porinès koreliacijos koeficientai patvirtina, kad tikslinga juos ittraukti ị ekonometrinị modelị vertinant ūkių ekonominị gyvybingumą.

Apibendrinant galima teigti, kad remiantis porine ir daline koreliacija vertinant ūkių ekonomini gyvybingumą pasirinkti tinkami veiksniai ir juos atspindintys finansiniai rodikliai (5-8 lentelès). Empirinis tyrimas parodè, kad pagrindinis veiksnys, teigiamai veikiantis ūkių ekonominio gyvybingumo rodiklius, yra gamybos subsidijos. Tai priklauso nuo valstybès politikos. Valstybės politikos ir valdymo struktūros stabilumas teigiamai veikia kiekvieno ūkio ekonomikos plètotę. Tačiau tada dirbtinai palaikomas ūkių ekonominis gyvybingumas ir neleidžiama adekvačiai palyginti ūkių privačių iniciatyvų sukuriant indèlị ir stiprinant ūkių ekonominio gyvybingumo pranašumus, ypač tuos, kurie veiksmingi ne tiek esamu laiku, kiek ilgą laikotarpi ateityje. Tai skatina tolesnius tyrimus ir kelia klausimą, kaip subsidijos ir ūkių apmokestinimo sistema kompleksiškai daro ịtaką ūkių ekonominiam gyvybingumui.

Tyrimas taip pat parodè, kad neigiamą ittaką ūkių ekonominiam gyvybingumui turi augančios sąnaudos, tačiau ūkis šiuos veiksnius gali kontroliuoti ir valdyti, todèl ūkio sèkmè ir plètra priklauso nuo gebejjimo išlaikyti ir padidinti ūkių ekonomini gyvybingumą. Kad ūkis sẻkmingai veiktų ir ilgą laiką išliktų rinkoje, reikia nuolatos kontroliuoti ekonomini gyvybingumą analizuojant ir atskleidžiant veiksnių reikšmingumą. Svarbu atrasti veiksnius, kurie didina žemès ūkio sektoriaus ekonomini gyvybingumą, nes mažejančios Vyriausybès paramos išmokos gali ūkius privesti prie finansinio išsekimo. Svarbu tinkamai prižiūrèti žemès ūkio paskirties žemę ir siekti socialinio suderinamumo, kad toliau būtų vykdoma sèkminga žemès ūkio veikla. 


\section{IŠVADOS}

1. Ivardinti finansiniai rodikliai, manytume, laikytini esmingiausiais vertinant ūkio ekonomini gyvybingumą, siekiant identifikuoti ekonominio gyvybingumo veiksnių ir juos atspindinčiu rodikliu reikšmingumą žemès ūkyje. Mokslininkų, nagrinëjusių šiuos klausimus, tyrimų rezultatai parodè, kad ūkio ekonominio gyvybingumo apibrèžimas yra sudetingas kintamasis, kurio koncepcija dar nèra išbaigta ir kuriam visapusišką paaiškinimą nèra lengva surasti, būtina toliau gilintis ì ūkio ekonominio gyvybingumo žemès ūkyje esmę. Rekomenduotina suformuluoti ūkio ekonominio gyvybingumo apibrèžimą siekiant nusakyti ūkio ekonominio gyvybingumo vertinimo rodiklius, nes iškyla palyginimo bei teisingo duomenų interpretavimo problema.

2. Ūkio ekonominị gyvybingumą lemiančių veiksnių analizè parodè, kad reikšmingiausi yra finansiniai veiksniai (turtas, nuosavas kapitalas, skolos, subsidijos, pajamos, sąnaudos ir pan.) ir juos apibūdinantys rodikliai, nes jie greičiausiai ir tiksliausiai atskleidžia ūkio veiklos trikdžius. Sprendžiant, kuriuos finansinius rodiklius taikyti, kurie rodikliai yra svarbiausi, buvo parinkti mokslinèje literatūroje dažniausiai sutinkami aštuoni ūkių ekonominio gyvybingumo vertinimo finansiniai rodikliai: kapitalo grąža, issipareigojimų ir bendrojo pelno santykis, sąnaudų ir pajamų santykis, gamybos subsidijų ir bendrojo pelno santykis, pardavimų pelningumas, turto pelningumas, skolu ir nuosavo kapitalo santykis ir patikrintas jų ryšio stiprumas vertinant ūkių ekonomini gyvybingumą (tyrimas atliktas Lietuvos ūkiuose). Tai iš dalies byloja apie rodiklių tinkamumą būti ekonometrinio modelio sudetyje (vertinant ūkių ekonominị gyvybingumą).

3. Atlikus Lietuvos ūkininkų ūkių ekonominį gyvybingumą nustatyta, kad, remiantis Scott pateiktomis gyvybingumo ribomis, finansiniai rodikliai patikimi (vertinant ekonomini gyvybingumą). Išskirtas vienas specifinis rodiklis (gamybos subsidiju ir bendrojo pelno santykis), kuris parodo, kad ūkiai išlieka gyvybingi tik finansinès paramos dèka, nes viršija nustatytą gyvybingumo ribą net 8 kartus. Reikia pastebèti, kad gauta finansiné parama teigiamai veikia daugeli finansinių rodiklių ir dirbtinai palaiko ūkių ekonominị gyvybingumą. Ūkininkai turi pasirinkti tinkamą valdy- mo strategiją, optimalius sprendimo rezultatus ir be gamybos subsidijų gerinti žemès ūkio veiklos rezultatus, sukurti ūkio pajamų ateičiai, nes apskaičiuotas investicijų grąžos rodiklis be subsidiju sumos yra neigiamas jau keletą metų.

4. Nustačius finansinių veiksnių reikšmingumo rodiklius (kapitalo grąžos, ịsipareigojimų ir bendrojo pelno santykio, sąnaudų ir pajamų santykio, gamybos subsidijų ir bendrojo pelno santykio), porinès ir dalinès koreliacijos pagalba nustatytas daugumos veiksnių stiprus ryšys ir reikšmingumas, išskyrus trumpalaikių ir ilgalaikių skolų veiksnius (kapitalo grąžos rodiklis). Reikšmingiausi veiksniai yra gamybos subsidijos ir sąnaudos. Gamybos subsidijos teigiamai veikia ūkių ekonominio gyvybingumo rodiklius, ūkių ekonomikos plètotę, tačiau šiuo atveju - dirbtinai palaiko ùkių ekonominị gyvybingumą. Sąnaudų augimas turi neigiamos įtakos ūkių ekonominiam gyvybingumui, tačiau ūkis šiuos veiksnius gali kontroliuoti ir valdyti, todèl ūkio sèkmè ir plètra priklauso nuo gebejjimo išlaikyti ir padidinti ūkių ekonomini gyvybingumą. Tai reiškia, kad pasirinkti rodikliai ūkio ekonominiam gyvybingumui vertinti yra tinkami ir svarbūs.

Gauta 20111215 Priimta 20120327

\section{LITERATŪRA}

1. Adelaja A., Garcia K. M., Gibson A. M., Lake M. C. 2007. The Future of Farmland Preservation Programs: From Retention to Viability and Resiliency. Paper presented at the Trans Atlantic Land Use Conference (TALUC). Michigan State University. 56 p. [žiūrèta 2011-01-21]. Prieiga per internetą: http://nercrd.psu.edu/taluc/Papers/ AdelajaGarciaGibson Lake The\%20 Future.pdf

2. Adelaja A. 2005. Preserving Farmland and Achieving Agricultural Viability in the State of Michigan. Policy Analysis Report. Michigan State University. 26 p. [žiūrèta 2011-08-21]. Prieiga per internetą: www.landpolicy.msu.edu/

3. Adelaja A., Sullivan K. 1998. Agriculture Viability at the Urban Fringe. Department of Agricultural, Food and Resource Economics, Cook College. Rutgers University. 32 p. [žiūrèta 2011-08-30]. Prieiga per internetą: http://njsustainingfarms. rutgers.edu/PDF/Agricultural Viability/at/theUrbanFringe/.pdf

4. Adelaja A., Sullivan K., Hailu G. H. 2011. Endogenizing the Planning Horizon in Urban Fringe Agriculture. Land Policy Institute. P. 66-67 
[žiūrèta 2011-11-11]. Prieiga per internetą: http:// www.sciencedirect.com/

5. Argiles J. M. 2001. Accounting information and the prediction of farm non-viability. The European Accounting Review. P. 73-105 [žiūrèta 2010-1011]. Prieiga per duomenų bazę: http://www.sciencedirect.com/

6. Baležentis A., Baležentis T. 2011. Kaimo darnaus vystymo strateginis valdymas: daugiakriterinio vertinimo metodai ir integruotas Lietuvos ūkininkų ùkių veiklos efektyvumo vertinimas. Vadybos mokslas ir studijos - kaimo verslu ir ju infrastruktūros pletrai. Nr. 1. P. 25-35.

7. Conner D., Colasanti K., Brent R. et al. 2010. Locally Grown Foods and Farmers Markets: Consumer Attitudes and Behaviors. Michigan State University. Sustainability. P. 742-756 [žiūrèta 2011-10-21]. Prieiga per internetą: www.mdpi. com/ 2071-1050/2/3/742/pdf

8. Cocciarelli S., Edison T., Smalley S. et al. 2011. Farm viability and development. Michigan Good Food Work Group Report Series. Michigan State University. 36 p. [žiūrèta 2011-07-21]. Prieiga per internetą: http://www.michiganfood.org/assets/ goodfood/docs/ FarmViability Report.pdf

9. Jucevičius R. ir kt. 2006. Lietuvos ekonomikos augimo ir konkurencingumo šaltiniu (veiksniu) kompleksine studija. KTU. Verslo strategijos institutas. 266 p. [žiūrèta 2011-03-20]. Prieiga per internetą: http://www.ukmin.lt/lt/strategija/doc/ Kompleksine\%20studija-2006_03_09-galutine.doc

10. Kriščiukaitienė I., Tamošaitienė A., Andrikienė S. 2010. Lietuvos ūkininku ūkių gamybinio potencialo kompleksinis vertinimas. Vadybos mokslas ir studijos - kaimo verslu ir ju infrastruktūros plètrai. Nr. 22(3). P. 87-95.

11. Liou F. 2008. Fraudulent financial reporting detection and business failure prediction models: a comparison. Managerial Auditing Journal. Vol. 23. No. 7. P. 650-662.

12. Popelier C. 2005. Farm Sector Economic Viability, Environmental Stewardship and Social Compatibility. Michigan State University. 36 p. [žiūrèta 2011-09-23]. Prieiga per internetą: http:// www.msu.edu/ popelie1/Thesis\%20Proposal $\% 20$ Final\%201-23.doc

13. Rakštys R., Serva E. 2005. Ūkio subjektu ekonominio gyvybingumo nustatymo problemos. Kaunas: LŽŨU leidykla. 4 p. [žiūrèta 2010-07-21]. Prieiga per internetą: http://baitas.lzuu.lt/ mazylis/julram/7/121.pdf
14. Scott J. 2001. The Nova Scotia Genuine Progress Index Soils and Agriculture Accounts. GPI Atlantic Canada. 71 p. [žiūrèta 2011-09-11]. Prieiga per internetą: http://www.gpiatlantic.org/pdf/agriculture/farmviability.pdf

15. Scott J. 2005. Farm and community viability report on interview results. GPI Atlantic Canada. 116 p. [žiūrèta 2011-09-21]. Prieiga per internetą: http://www.gpiatlantic.org/pdf/ agriculture/ farmviab.pdf

16. Scott J., Colman R. 2008. The GPI soils and agriculture accounts. Economic viability of farms and farm communities in Nova Scotia and Prince Edward Island-an update. GPI Atlantic Canada. $98 \mathrm{p}$. [žiūrèta 2011-07-22]. Prieiga per internetą: http:// www.gpiatlantic. org/pdf/agriculture/ farmviab. pdf

17. Scotti E., Bergmann H., Henke R. et al. 2011. Evaluation of income effects of direct support. EEIG AGROSYNERGIE. Final Report. 261 p. [žiūrèta 2011-09-29]. Prieiga per internetą: http:// ec.europa.eu/agriculture/eval/reports/income/ fulltext_en.pdf

18. Singh M., Bhillar A. S., Joshi A. S. 2009. Factors Influencing Economic Viability of Marginal and Small Farmers in Punjab. Agricultural Economics Research Review. Vol. 22. P. 269-279. [žiūrèta 2010-10-11]. Prieiga per duomenų bazę: http:// www.sciencedirect.com/

19. Vinciūnienė V., Rauluškevičienė J. 2009. Lietuvos respondentinių ūkininkų ūkių techninio ir masto efektyvumo neparametrinis vertinimas. $L \check{Z} U U$ mokslo darbai. No. 85(38). P. 39-46.

20. Vrolijk H. C. J., Bont de C. J., Blokland P. W. Et al. 2010. Farm Viability in the European Union. LEI, Wageningen UR, Hagos. P. 1-69 [žiūrèta 201104-09]. Prieiga per internetą: http://www.lei. dlo. nl/publicaties/PDF/2010/2010-011.pdf

21. Whitaker J. B. 2009. The Varying Impacts of Agricultural Support Programs on U. S. Farm Household Consumption. American Journal of Agricultural Economics. No. 91(3). P. 569-580 [žiūrèta 2010-11-11]. Prieiga per duomenų bazę: http://www.science direct.com/

22. Федорченко А. 2008. Экономическая жизнеспособность палестинского государства. Аналитические доклады НКСМИ МГИМО (У) МИД России. № 2(21). С. 3-70 [žiūrèta 2012-01-11]. Prieiga per internetą: http://www. baxi-stavropol.ru/yekonomicheskaj_zhiznesposobnost.html 
Jūratė Savickienè, Astrida Slavickienè

EVALUATION OF INDICATORS INFLUENCING

THE ECONOMIC VIABILITY UNDER THE LITHUANIAN FARMERS' PROPERTY EXAMPLE

Sum mary

The scientific researches lack the attention on evaluation of the economic viability of farmers' farms, choosing the right models of evaluation and their implementation. Therefore the scientific problem of this article, which is to evaluate the effect of factors on the economical viability and identify the main indicators defining the economical viability, remains relevant and is analysed in this article. The scientists' researches have revealed that the definition of the economical farms viability is a complex variable, that has an unfinished conception and is not easy to comprehensively explain; therefore it is necessary to formulate the definition, at least for the local research matters, in order to define the evaluation indicators of the farms economical viability as the problem of comparison and suitable data interpretation arises. The factors determining the economic viability of farms and the financial indicators evaluating the Lithuanian farmers' farms are systemised in this article and should be considered the most relevant for evaluating the farms' economical viability. The economical farms' viability indicators most rapidly revealing disturbances in the farm's activity were determined. The problem still remains as follows - what financial indicators should be implemented, and which ones are more important. The financial indicators most commonly used in the scientific literature were taken to carry out this research, and it was ascertained that the chosen indicators are suitable and important for evaluation of the farms' viability.

Key words: economic viability, evaluation of the economic viability, financial factors, financial indicators, farmer's farm, analysis 